\title{
FAKTOR YANG MEMPENGARUHI KEPUASAN KERJA DAMPAKNYA PADA KINERJA PEGAWAI
}

\author{
Bayu Indra Setia \\ bayu_indrasetia@unpas.ac.id \\ Erry SR. Pangestu \\ Universitas Pasundan \\ J1. Tamansari No. 6-8, Bandung 40116
}

diterima: 19/12/2019; direvisi: 27/4/2020; disetujui: 28/8/2020

\begin{abstract}
The basic needs of society and human rights are food which has meaning and a very important role for the life of a nation. The problem in food security implies that no single policy can solve all problems at once. This research aims to see, analyze and examine the factors that affect employee job satisfaction as assessed through visionary leadership, work motivation and competence and their impact on employee performance partially and simultaneously. As many as 105 employees studied with the saturated sample method. The method used is descriptive survey and explanatory survey methods, for data analysis using path analysis. In general, the results of this research indicate that visionary leadership is in the good category and for motivation, competence and satisfaction as well as performance is in the good enough category. The results of data analysis show that the influence of leadership, work motivation and competence on job satisfaction is $62.1 \%$, and the effect of job satisfaction on performance is $76.9 \%$.
\end{abstract}

Keywords: visionaryleadership; workmotivation; competence;job satisfaction; employeeperformance

\begin{abstract}
Abstrak
Kebutuhan masyarakat yang mendasar dan merupakan hak asasi manusia adalah pangan yang mempunyai arti dan peran sangat penting bagi kehidupan suatu bangsa. Masalah yang dihadapi dalam ketahanan pangan mengisyaratkan tidak ada single policy yang dapat mengatasi semua persoalan sekaligus. Penelitian ini bertujuan untuk mengetahui, menganalisa dan mengkaji factor yang mempengaruhi kepuasan kerja pegawai yang diukur melalui kepemimpinan visioner, motivasi kerja dan kompetensi dan dampaknya pada kinerja pegawai baik secara parsial dan simultan. Pegawai yang diteliti sebanyak 105 pegawai dengan metode sampel jenuh. Metode yang digunakan adalah descriptive survey dan metode explanatory survey, untuk analisis data dengan menggunakan analisis jalur. Secara umum hasil penelitian ini menunjukkan kepemimpinan visioner masuk dalam kategori baik dan untuk motivasi, kompetensi dan kepuasan serta kinerja masuk kedalam kategori cukup baik. Hasil analisis data menunjukkan besarnya pengaruh kepemimpinan visioner, motivasi kerja dan kompetensi terhadap kepuasan kerja sebesar $62,1 \%$, dan pengaruh kepuasan kerja terhadap kinerja sebesar 76,9\%.
\end{abstract}

Kata Kunci: kepemimpinan visioner; motivasi kerja; kompetensi; kepuasan kerja; kinerja karyawan 


\section{PENDAHULUAN}

Hakekat pembangunan nasional adalah pembangunan manusia Indonesia seutuhnya dan pembangunan masyarakat Indonesia seluruhnya. Pembangunan dilaksanakan merata di seluruh tanah air dan harus benar-benar dapat dirasakan oleh seluruh masyarakat Indonesia sebagai perbaikan tingkat hidup yang berkeadilan sosial. Salah satu keberhasilan dalam pembangunan adalah sumber daya manusia yang berkualitas dan memiliki keterampilan serta penguasaan IPTEK dalam menghadapi globalisasi, antara lain menjaga kestabilan ekonomi makro, meningkatkan kualitas sumber daya manusia yaitu kompetensi dalam komitmen melalui demokratisasi pendidikan, penguasaan IPTEK.

Ilmu pengetahuan dan teknologi merupakan salah satu kunci kemajuan suatu bangsa yang peranannya semakin dominan. Globalisasi adalah suatu hal yang tidak dapat dihindari saat ini, globalisasi akan mempengaruhi seluruh perikehidupan manusia Indonesia, khususnya bidang ekonomi. Globalisasi tidak boleh menghilangkan semangat, karakter dan budaya Indonesia maka bangsa Indonesia harus mempunyai daya tahan dan daya saing bangsa. Daya saing merupakan semangat memperbaiki diri sehingga menjadi bangsa yang kompetitif secara nasional melalui kompetensi dan komitmen.

Lemahnya daya saing sumber daya manusia nasional menyebabkan Indonesia harus mampu meningkatkan kualitas sumber daya manusia dalam kancah persaingan global. Kondisi dan permasalahan Indonesia yang multi komplek harus dilakukan perubahan yaitu membangun kualitas sumber daya manusia melalui pendidikan yang dapat menghasilkan kinerja yang optimal merupakan tuntutan bagi perusahaan untuk memenuhi kebutuhan masyarakat sesuai dengan aturan yang ada baik aturan pemerintah maupun aturan perusahaan itu sendiri.

Kebutuhan masyarakat yang mendasar dan merupakan hak asasi manusia adalah pangan yang mempunyai arti dan peran sangat penting bagi kehidupan suatu bangsa sebagaimana tersebut dalam pasal 27 UUD 1945 maupun dalam Deklarasi Roma (1996). Ketersediaan pangan disuatu negara yang lebih kecil dibandingkan kebutuhannya dapat menciptakan ketidakstabilan ekonomi. Berbagai gejolak sosial dan politik dapat juga terjadi jika ketahanan pangan terganggu. Kondisi kritis ini bahkan dapat membahayakan stabilitas nasional yang dapat meruntuhkan pemerintah yang sedang berkuasa. Bagi Indonesia, pangan diidentikan dengan beras karena jenis pangan ini merupakan makanan pokok utama. Pengalaman telah membuktikan kepada kita bahwa gangguan pada ketahanan pangan seperti meroketnya kenaikan harga beras pada waktu krisis ekonomi 1997/1998, yang berkembang menjadi krisis multidimensi, telah memicu kerawanan sosial yang membahayakan stabilitas ekonomi dan stabilitas Nasional (http://www.bulog.co.id).
Komitmen nasional dan dunia untuk mewujudkan ketahanan pangan didasarkan atas peran strategis perwujudan ketahanan pangan dalam memenuhi salah satu hak asasi manusia, membangun kualitas sumber daya manusia dan membangun pilar ketahanan nasional. Peran memenuhi salah satu hak asasi manusia dinyatakan dalam UU No. 7/1996 tentang Pangan, bahwa hak setiap orang untuk memperoleh pangan yang aman dan bergizi sama prinsipnya dengan hak memperoleh pangan yang cukup dan hak asasi manusia untuk bebas dari kelaparan.

Masalah yang dihadapi dalam ketahanan pangan mengisyaratkan tidak ada single policy yang dapat mengatasi semua persoalan sekaligus. Hal ini dapat dipahami karena ketahanan pangan menyangkut banyak aspek dan dengan sendirinya terkait dengan berbagai stakeholders. Untuk itu dalam memperkuat ketahanan pangan dituntut upaya yang teringrasi dari semua pemangku kepentingan sehingga mampu melahirkan kebijakan yang komprehensif.

Perum Bulog merupakan perusahaan umum milik negara yang bergerak di bidang logistik pangan. Ruang lingkup bisnis perusahaan meliputi usaha logistik/ pergudangan, survei dan pemberantasan hama, penyediaan karung plastik, usaha angkutan, perdagangan komoditi pangan dan usaha eceran. Sebagai perusahaan yang tetap mengemban tugas publik dari pemerintah, Bulog tetap melakukan kegiatan menjaga harga dasar pembelian untuk gabah, stabilisasi harga khususnya harga pokok, menyalurkan beras untuk orang miskin (Raskin) dan pengelolaan stok pangan (http://www. bulog.co.id).

Peran Perum Bulog terhadap ketahanan Ekonomi Nasional melaksanakan stabilitas harga bahan pokok pangan, ketersediaan stock beras yang cukup dan aman dalam memenuhi kebutuhan seluruh masyarakat Indonesia pendistribusian untuk RASKIN serta market operation diperlukan kualitas sumber daya manusia yang handal yang digunakan secara efektif dan efisien guna mendukung pembangunan nasional. Peran pangan sangat strategis yang merupakan kebutuhan dasar manusia dan menempati prioritas yang tinggi dalam pembangunan ekonomi suatu bangsa.

Perum Bulog sebagai lembaga pelaksana kebijakan pemerintah, telah mendukung dan melaksanakan beberapa program prioritas yang dicanangkan oleh pemerintah, seperti penanganan rawan pangan dan pengembangan distribusi melalui program RASKIN sejak tahun 1998, dan selalu menjaga stabilisasi harga melalui kegiatan pembelian gabah dan beras petani sebagai upaya menyeimbangkan supply-demand beras di pasar, sehingga petani dapat menjual produknya dengan harga wajar dan menguntungkan pada saat panen. Pada sisi lain konsumen tidak terbebani dengan harga beras yang tinggi pada musim paceklik.

Perum Bulog Sub Divisi Regional Bandung (Sub Divre Bandung), merupakan salah 1 dari 7 Sub Divisi 
Regional yang berada dibawah naungan Perum Bulog Divisi Regional Jawa Barat (Divre Jabar). Tugas pokoknya adalah mendistribusikan beras bersubsidi bagi masyarakat berpendapatan rendah, dimulai dari gudang sampai ke titik distribusi (http://www.bulog.co.id).

Dalam rangka mendukung keberhasilan tugas Perum Bulog Pusat, Perum Bulog Subdivre Bandung mengemban visi dan misi sangat berat dan diperlukan kinerja pegawai yang optimal, efektif dan efisien.

Kinerja pegawai menurut Dessler (2011:330) adalah employee's actual performance compared to the expected performance of the employees, sedangkan menurut Mangkunegara, (2016:67) kinerja adalah hasil kinerja secara kualitas dan kuantitas yang dicapai oleh seseorang pegawai dalam melaksanakan tugasnya sesuai dengan tanggung jawab yang diberikan kepadanya. Menurut Gibson (2012:104) kinerja adalah job formance yaitu hasil pekerjaan yang terkait dengan tujuan organisasi, efisiensi dan keefektifan kerja. Kinerja merupakan pencapaian hasil dalam rangka mewujudkan hasil dalam rangka mewujudkan tujuan organisasi

Hasil pengamatan dilapangan dan wawancara kepada beberapa pegawai mulai dari kepala gudang sampai ke bagian SDM serta infomasi lainnya, ternyata kinerja pegawai Perum Bulog Subdivre Bandung masih menunjukan kinerja yang belum maksimal, karena masih terdapat beberapa kecamatan atau kelurahan yang terlambat dalam pendistribusiannya hal ini disebabkan karena adanya faktor posisi stok atau status persediaan beras di masing-masing gudang yang berbeda dan fluktuatif setiap periodenya, sedangkan kebutuhan beras dimasing-masing wilayah besarannya sudah ditetapkan sesuai dengan jumlah Rumah Tangga Sasaran Penerima Manfaat (RTS-PM) berdasarkan Surat Keputusan Pemerintah Daerah melalui SK Pagu Raskin, (http:// www.bulog.co.id).

Berdasarkan data pada Tabel 1 dapat dilihat bahwa ada ketimpangan antara pengadaan dengan penyaluran, artinya ada masyarakat yang tidak menerima bantuan beras sesuai dengan Minimum Stock Requirement (MSR), atau pengadaan yang banyak tetapi tidak tepat sasaran penerima bantuan beras.

Dalam pengadaan dan penyaluran stok beras/gabah, kualitas beras/gabah, pemeliharaan gudang, kantor dan sarana prasarana memerlukan kehandalan dan ketangguhan dari pegawai. Hal tersebut menjadi salah satu hambatan meningkatkan kinerja pegawai dalam hal kerjasama baik antara pegawai dengan pimpinan maupun antar pegawai. Faktor yang dapat mempengaruhi kinerja pegawai adalah kepuasan kerja yang terpenuhi oleh perusahaan, untuk itu perusahaan harus menjamin faktor yang berkaitan dengan kepuasan kerja sebagai unsur yang dapat berpengaruh terhadap kinerja pegawai.

Kepuasan kerja pada dasarnya memiliki tingkat kepuasan yang berbeda-beda sesuai dengan sistem nilai yang berlaku pada dirinya. Robbins (2017:170) menyatakan bahwa kepuasan kerja adalah suatu sikap umum terhadap pekerjaan seseorang sebagai perbedaan antara banyaknya ganjaran yang diterima pekerja dengan banyaknya ganjaran yang diyakini seharusnya diterima.

Kepuasan kerja timbul karena pegawai banyak terlibat dalam organisasi dan memberikan dampak positif bagi organisasi (Posdakoff, et. al. 1996). Menurut Guo \& Wu (2015) dalam penelitiannya bahwa kinerja pegawai akan baik bila pegawai mempunyai keahlian yang tinggi, kesediaan untuk bekerja, adanya upah yang banyak dan harapan masa depan yang baik.

Berdasarkan hasil pengamatan yang dilakukan ditemukan beberapa masalah terkait dengan kepuasan kerja dari pegawai, yaitu monitoring dan evaluasi pegawai yang belum terlaksana dengan baik. Monitoring dan evaluasi tersebut menurut para pegawai memiliki manfaat sebagai tolak ukur dan keberhasilan program atau kebijakan yang dilaksanakan. Monitoring dan evaluasi sangat berperan terhadap kepuasan kerja karena dapat memberikan dampak positif kepada pegawai seperti akan membuat pekerjaan menjadi lebih terkontrol sehingga pegawai akan merasa puas dengan hasil kerja mereka dan mendukung keberhasilan kerja perusahaan. Keberhasilan kerja perusahaan tidak akan berjalan dengan lancar tanpa campur tangan pemimpin.

Pimpinan dalam perusahaan di harapkan bisa menciptakan keadilan bagi pegawai agar bekerja secara maksimal. Kebijakan pimpinan yang diharapkan pegawai adalah pimpinan yang mampu memberikan kepuasan bagi pegawainya baik secara materiil maupun non materiil. Dengan meningkatnya kepuasan kerja akan berpengaruh pada kinerja pegawai yang optimal.

Kepemimpinan adalah kemampuan untuk mempengaruhi dan memotivasi orang lain, sehingga mereka bertindak dan berperilaku sebagaimana yang diharapkan tujuan organisasi, (Mangkunegara, 2016).

Pemimpin dalam menggerakkan para pegawainya harus memperhatikan kebutuhan yang harus dipenuhi dalam memotivasi pegawai. Pemenuhan kebutuhan dalam organisasi dapat mendorong pegawai untuk mencapai tujuan organisasi.

Salah satu model kepemimpinan adalah kepemimpinan visioner. Kepemimpinan Visioner sebagai respon dari statement the only thing of permanent is change yaitu menuntut seorang pemimpin memiliki kemampuan dalam menentukan arah masa depan melalui visi. Visi merupakan pemikiran pemimpin tentang masa depan organisasi yang shared dengan stake holders dan merupakan kekuatan kunci bagi pertambahan dalam menciptakan kemajuan organisasi dan antisipasi dalam persaingan global. (Nanus, 1992; Nindyati (2013).

Kepemimpinan visioner sangat diperlukan pada kondisi meningkatkan intensitas persaingan bisnis saat ini, karena kepemimpinan visioner mencakup upaya untuk mengantisipasi perubahan sehingga diyakini akan mampu menciptakan dan mempertahankan kinerja yang superior dibandingkan pesaing. 
Kepemimpinan visioner adalah visi yang harus dimiliki berdasarkan rambu-rambu untuk mewujudkan visi dan misi Perum Bulog. Dalam pelaksanaan visi Perum Bulog diperlukan Kepemimpinan visioner yaitu kemampuan pemimpin dalam menciptakan, merumuskan, mengkomunikasikan, mensosialisasikan, mentranformasikan, mengimplementasikan pemikiran yang ideal sebagai hasil interaksi sosial diantara pegawai Perum Bulog dan stake holder yang diyakini sebagai cita-cita di masa depan.

Peran pemimpin visioner membentuk dan memberdayakan pegawai, menghidupkan visi (tujuan) dan membangun kepercayaan pegawai, (Nanus, 1992). Menurut Sastrohadiwinarto (2005), bahwa pegawai sebagai manusia memerlukan kebutuhan. Setiap perasaan, kehendak atau keinginan sangat mempengaruhi kemauan individu, sehingga individu tersebut didorong untuk berperilaku dan bertindak kepada tujuan organisasi.

Berdasarkan hasil pengamatan yang dilakukan dengan cara wawancara kepada pegawai Perum Bulog subdivre Bandung, menyatakan bahwa kepemimpinan visioner belum dilakukan secara maksimal oleh pemangku jabatan atau pimpinan, karena masih belum mampu memberikan keunggulan-keunggulan bagi organisasi agar terus hidup dan berkembang. Pemimpin kurang punya inisiatif dan inovasi terhadap perkembangan perusahaan, hanya melaksanakan rutinitas tidak ada gebrakan yang bisa menjadi keunggulan Perum Bulog. Selain itu pegawai masih kurang merasakan pengamanan keselamatan, kesehatan dan kompensasi yang diberikan oleh perusahaan yang akan berdampak pada kepuasan kerja pegawai.

Factor lain yang mempengaruhi kepuasan kerja adalah motivasi yang merupakan serangkaian sikap dan nilai-nilai yang mempengaruhi individu untuk mencapai tujuan kompetensi seorang pemimpin harus mempunyai keterampilan, pengetahuan dan perilaku yang baik.

Motivasi kerja pegawai bertujuan mendorong semangat kemajuan dalam mencapai tujuan perusahaan, apabila kebutuhan manusia sebagai pegawai terpenuhi kebutuhannya. Dengan kebutuhan fisiologi, security, sosial, harga diri dan aktualisasi disamping pengamanan keselamatan, kesehatan, hubungan harmonis sesama rekan dan atasan terpenuhi maka akan meningkatkan kepuasan kerja pegawai (Mangkunegara, 2016; mengutip Herz Berg).

Motivasi sangat penting bagi tinggi rendahnya produktivitas perusahaan. Jika para karyawan memiliki motivasi rendah untuk bekerja,baik secara personal maupun bekerja sama dengan rekannya bagi kepentingan perusahaan, maka tujuan yang telah ditetapkan tidak tercapai. Sebaliknya jika para karyawan memiliki motivasi tinggi maka hal tersebut dapat menjadi jaminan atas keberhasil perusahaan dalam mencapai tujuan.
Berdasarkan wawancara dengan bagian SDM motivasi pegawai masih kurang baik, yang ditunjukan dengan masih rendahnya pegawai mentaati peraturan yang ada diperusahaan, seperti banyak pegawai yang suka terlambat masuk kerja, dan waktu istirahat yang tidak menentu. Sehingga perusahaan selalu mengamati itu yang berdampak pada kepuasan kerja yang tidak bisa dipenuhi oleh perusahaan. Dengan demikian ada perusahaan dengan pegawai kurang harmonis.

Selain kepemimpinan visioner dan motivasi kerja yang mempengaruhi kepusaan kerja, juga yang tidak kalah pentingnya adalah kompetensi dari pegawai. Dalam menangani pengadaan stok beras yang cukup diperlukan sumber daya manusia yang terampil dan menguasai pengetahuan quality control agar kualitas beras yang baik sesuai Standar Kualitas yang telah ditetapkan pemerintah.

Kualitas SDM dapat dilihat dari kompetensi dan pengetahuan Iptek serta keterampilan kerja dalam melaksanakan tugas dan fungsinya di bidang masingmasing. Kompetensi sebagai suatu kemampuan untuk melaksanakan pekerjaan oleh pegawai dalam mencapai tujuan. Menurut Finch dan Crunkilton (1999); kompetensi terhadap suatu tugas, keterampilan, sikap dan opinion untuk menunjang keberhasilan. Oleh karena itu terdapat pengaruh kompetensi kerja terhadap kepuasan kerja.

Kompetensi pegawai yang dimiliki oleh Perum Bulog masih kurang baik karena masih ada beberapa pegawai yang masih memiliki Pendidikan yang tidak sesuai dengan aturan, meskipun telah dilakukan pelatihan keterampilan tetapi masih kurang maksimal. Berdasarkan hasil wawancara dengan bagian SDM dan beberapa pegawai di Perum Bulog Subdivre Bandung yang menjadi permasalahan sekarang adalah belum terciptanya kesadaran pegawai dalam meningkatkan kemampuan untuk meningkatkan daya saing perusahaan, Perencanaan program pendidikan dan pelatihan pegawai masih belum dilakukan dengan baik untuk meningkatkan pelaksanaan tugas dibidangnya masing-masing, serta diperlukan pengetahuan dan keterampilan dalam menunjang pengembangan kualitas beras dan kemasan yang baik dalam meningkatkan daya saing perusahaan.

Berdasarkan fenomena diatas maka tujuan penelitian ini adalah untuk mengetahui, mengkaji dan menganalisis seberapa besar pengaruh kepemimpinan visioner, motivasi dan kompetensi terhadap kepuasan kerja yang berdampak pada kinerja pegawai baik secara simultan maupun parsial.

\section{METODE}

Metode yang digunakan adalah deskriptif dan eksplanatori. Teknik sampling yang digunakan adalah sampel jenuh sebanyak 105 pegawai, Metode analisis data yang digunakan yaitu analisis jalur. Skala 
pengukuran yang digunakan adalah ordinal yang dalam perhitungan diubah menjadi interval dengan menggunakan methode successive interval (MSI). Pengujian instrumen dengan menggunakan uji validitas dan reliabilitas dengan rumus korelasi berdasarkan Pearson product moment, dengan hasil bahwa seluruh variabel dengan masing-masing 15 item pertanyaan dinyatakan valid dan reliabel.

\section{HASIL}

Karakteristik responden yang digunakan yaitu berdasarkan jenis kelamin, usia, tingkat pendidikan. Karakteristik responden menurut jenis kelamin, sebagian besar pegawai didominasi oleh lakilaki, yaitu $90 \%$, sedangkan karateristik responden berdasarkan usia lebih dari 46 tahun atau sebesar $61 \%$, sedangkan minoritas pegawai berusia kurang dari 25 tahun, yaitu hanya 3\% saja. Jika dilihat karakteristik responden berdasarkan pendidikan diperoleh bahwa mayoritas besar dari pegawai berpendidikan SMA sebesar $87 \%$.

Hasil analisis deskriptif, kepemimpinan visioner menunjukkan skor total mencapai 6450 dikategorikan baik. Skor total motivasi mencapai 6068 dikategorikan cukup baik. Skor total kompetensi mencapai 6032 dikategorikan cukup tinggi. Skor total kepuasan kerja mencapai 5963 dikategorikan cukup tinggi, dan Skor total kinerja mencapai 6237 dikategorikan cukup tinggi.

Berdasarkan pada hasil perhitungan dengan menggunakan SPSS 20, maka diperoleh hasil analisis jalur sebagaimana pada Gambar 1.

Persamaan analisis jalur pada penelitian ini sebagai berikut:

struktural 1

$\mathrm{Y}=0,336 \mathrm{X}_{1}+0,251 \mathrm{X}_{2}+0,338 \mathrm{X}_{3}, \mathrm{R}^{2}=0,621 \ldots . .(1)$

$$
\begin{aligned}
& \text { struktural } 2 \\
& \qquad \mathrm{Z}=0,877 \mathrm{Y}+\varepsilon_{2}, \mathrm{R}^{2}=0,769 .
\end{aligned}
$$

Berdasarkan hasil persamaan struktural 1 bahwa koefisien determinasi $\left(\mathrm{R}^{2}\right)$ sebesar 0.621 berarti bahwa $62.1 \%$ variabilitas variabel kepuasan kerja dapat diterangkan oleh variabel bebas $\mathrm{X}_{1}$ (kepemimpinan visioner), $\mathrm{X}_{2}$ (motivasi), dan $\mathrm{X}_{3}$ (kompetensi) sedangkan pengaruh variabel diluar model sebesar 37,9\% (errorvar $=37,9$ ). artinya terdapat pengaruh yang signifikan secara simultan antara $X_{1}$ (kepemimpinan visioner), $X_{2}$ (motivasi), dan $\mathrm{X}_{3}$ (kompetensi) terhadap $\mathrm{Y}$ (kepuasan kerja) sebesar $62,1 \%$ (Tabel 1).

Pengaruh langsung variabel kepemimpinan visioner terhadap kepusan kerja adalah sebesar 11,29\%. Sedangkan pengaruh tidak langsung kepemimpinan visioner melalui motivasi kerja sebesar 4,93\%, dan melalui kompetensi sebesar 5,04\%. Dengan demikian pengaruh kepemimpinan visioner terhadap kepuasan kerja baik secara langsung maupun tidak langsung sebesar $21,26 \%$.
Pengaruh motivasi secara langsung terhadap kepuasan kerja sebesar $6,31 \%$. sedangkan secara tidak langsung melalui kepemimpinan visioner sebesar 4,93\% dan melalui kompetensi sebesar 6,55\%. Dengan demikian pengaruh motivasi terhadap kepuasan kerja baik secara langsung maupun tidak langsung sebesar $17,79 \%$.

Pengaruh kompetensi secara langsung terhadap kepuasan kerja sebesar $11,43 \%$. sedangkan secara tidak langsung melalui kepemimpinan visioner sebesar 5,04\% dan melalui motivasi sebesar 6,55\%. Dengan demikian pengaruh kompetensi terhadap kepuasan kerja baik secara langsung maupun tidak langsung sebesar 23,02\%.

Berdasarkan hasil persamaan substruktur 2 bahwa koefisien determinasi $\left(\mathrm{R}^{2}\right)$ sebesar 0,769 berarti bahwa $76,9 \%$ kinerja pegawai dapat diterangkan oleh kepuasan kerja sedangkan pengaruh variabel diluar model sebesar $23,1 \%$ (errorvar $=23.1)$. artinya terdapat pengaruh yang signifikan secara simultan antara Y (kepuasan kerja) terhadap kinerja pegawai sebesar 76,9\% (Tabel 2). Berdasarkan hasil tersebut disimpulkan bahwa kepuasan kerja dapat meningkatkan kinerja pegawai dilihat dari kepemimpinan visioner, motivasi dan kompetensi.

\section{PEMBAHASAN}

Pengujian atas hipotesis kepemimpinan visioner terhadap kepuasan kerja dapat diperoleh kesimpulan bahwa kepemimpinan visioner mempengaruhi secara signifikan terhadap kepuasan kerja. Pengaruh langsung kepemimpinan visioner terhadap kepuasan kerja memiliki pengaruh yang besar dibandingkan dengan pengaruh tidak langsungnya. Pengaruh tidak langsung kepemimpinan visioner melalui kompetensi merupakan pengaruh yang paling besar dibandingkan melalui motivasi. Artinya bahwa semakin baik kepemimpinan visioner, maka semakin tinggi kepuasan kerja. Dapat dijelaskan lebih lanjut bahwa kepemimpinan visioner dan kepuasan kerja merupakan variabel yang berkaitan dan saling mendukung.

Hal ini sesuai dengan penelitian Nanus (1992) dimana hasil penelitiannya, menemukan bahwa terdapat peran pemimpin visioner membentuk dan memberdayakan pegawai, menghidupkan visi (tujuan) dan membangun kepercayaan pegawai, memotivasi pegawai. Hal tersebut melalui proses yang berjalan terus-menerus dan pengalaman kerja mempengaruhi kepuasan kerja. Pola kepemimpinan yang ditunjukkan di dalam kerja maupun usaha dilakukan sudah berdasarkan visi yang jelas. Kemampuan pemimpin dalam menciptakan, merumuskan, mentransformasikan dan mengimplementasikan pemikiran-pemikiran ideal yang berasal dari dirinya atau sebagai hasil interaksi sosial di antara anggota organisasi dan stakeholder yang diyakini sebagai cita-cita organisasi di masa depan yang harus diraih atau diwujudkan melalui komitmen semua personil sudah berdasarkan rambu-rambu untuk mewujudkan visi dan misi Perum Bulog. 
Selain Nanus penelitian yang mendukung penelitian ini adalah Xenikou \& Simosi, (2006); Avolio, et. al (1988); Bass, B.M, (1990); Coad \& Berry (1998) yang menyatakan hal serupa bahwa, kepemimpinan visioner akan membentuk kepuasan kerja yang baik.

Hasil penelitian yang dilakukan oleh Sunya, et. al. (2017), Anshar (2017), mengemukakan bahwa kepemimpinan visioner berpengaruh secara signifikan terhadap kepuasan kerja, karena dengan kepemimpinan yang memiliki visi yang jelas, akan melaksanakan terobosan baru untuk meningkatkan kepuasan kerja pegawai.

Pengujian atas hipotesis pengaruh motivasi terhadap kepuasan kerja dapat diperoleh kesimpulan bahwa motivasi berpengaruh terhadap kepuasan kerja. Artinya, bahwa motivasi dapat memberikan kesetiaan pegawai terhadap organisasi. Maka hipotesis yang menyatakan motivasi berpengaruh terhadap kepuasan kerja diterima. Motivasi berpengaruh secara positif terhadap kepuasan kerja, dengan kata lain setiap kenaikan motivasi, akan meningkatkan kepuasan kerja.

Pengaruh tidak langsung motivasi kerja terhadap kepuasan kerja memiliki pengaruh yang besar dibandingkan dengan pengaruh langsungnya. Pengaruh tidak langsung motivasi melalui kompetensi merupakan pengaruh yang paling besar dibandingkan melalui kepemimpinan visioner.

Temuan ini didukung hasil penelitian Sastrohadiwinarto (2005) bahwa pegawai sebagai manusia memerlukan kebutuhan. Setiap perasaan, kehendak atau Keinginan sangat mempengaruhi kemauan individu, sehingga individu tersebut didorong untuk berperilaku dan bertindak kepada tujuan organisasi, oleh karena itu motivasi kerja berpengaruh kepada kepuasan kerja.

Motivasi dapat mempengaruhi individu dan menggerakkan diri pegawai secara terarah atau tertuju untuk mencapai tujuan organisasi, sehingga kepentingankepentingan pribadi para anggota organisasi tersebut akan terpelihara pula dan tercipta kesetiaan pegawai terhadap organisasi.

Hasil ini konsisten dengan studi empiris yang dilakukan oleh Mangkunegara (2016). Motivasi kerja pegawai bertujuan mendorong semangat kemajuan dalam mencapai tujuan, apabila kebutuhan manusia sebagai pegawai terpenuhi kebutuhannya. Kebutuhan fisiologi, security, sosial, harga diri dan aktualisasi disamping pengamanan keselamatan, kesehatan, hubungan harmonis sesama rekan dan atasan sebagai kepuasan kerja bagi pegawai, oleh karena itu motivasi kerja berpengaruh pada kepuasan kerja.

Hasil yang ditemukan oleh Adam \& Kamase. (2019), Arif, et. al. (2019) mengemukakan bahwa motivasi yang dilakukan oleh perusahaan semata-mata untuk meningkatkan kepuasan kerja pegawai, oleh karena itu pengaruh motivasi terhadap kepuasan kerja memiliki pengaruh yang signifikan, serta berdampak pada kinerja pegawai.
Pengaruh tidak langsung kompetensi terhadap kepuasan kerja memiliki pengaruh yang besar dibandingkan dengan pengaruh langsungnya. Pengaruh tidak langsung kompetensi melalui motivasi merupakan pengaruh yang paling besar dibandingkan melalui kepemimpinan visioner. Pengujian atas hipotesis pengaruh kompetensi terhadap kepuasan kerja dapat diterima diperoleh kesimpulan bahwa kompetensi berpengaruh positif terhadap kepuasan kerja secara signifikan. Kompetensi yang baik akan memberikan kepuasan kerja yang tinggi.

Kompetensi sebagai suatu kemampuan untuk melaksanakan pekerjaan oleh pegawai dalam mencapai tujuan. Kemampuan pegawai dalam melaksanakan pekerjaan yang dihasilkan dan dididukung perusahaan merupakan kepuasan kerja pegawai.

Menurut Finch dan Crunkilton (1999), kompetensi terhadap suatu tugas, keterampilan, sikap dan opinion untuk menunjang keberhasilan. Oleh karena itu terdapat pengaruh kompetensi kerja terhadap kepuasan kerja.

Hasil yang dikemukakan oleh Renyut (2017), Mukhtar, A. (2018) menemukan bahwa kompetensi yang dimiliki oleh para pegawai menentukan tingkat kepuasan kerja. Semakin pegawai diberikan pelatih untuk meningkatkan kompetensi, maka kepuasan kerja pegawai akan meningkat, karena pegawai merasa diperhatikan dalam softskill maupun hardskillnya.

Hasil penelitian ini membuktikan bahwa kompetensi kerja yang diukur oleh 4 (empat) dimensi, yaitu keterampilan, pengetahuan, penguasaan pribadi, harapan dengan usaha ternyata dapat meningkatkan kepuasan kerja. Kompetensi sebagai penguasaan terhadap suatu tugas, keterampilan, sikap dan organisasi yang diperlukan untuk menunjang keberhasilan. Kompetensi sebagai pengetahuan dan keahlian untuk meningkatkan kemampuan sumber daya manusia dalam melaksanakan tugas dan tanggung jawab pada perusahaan, oleh karena itu berpengaruh pada kepuasan kerja.

Kepuasan kerja memiliki pengaruh sebesar $76.9 \%$ terhadap kinerja pegawai. Semakin tinggi kepuasan kerja pegawai maka kinerja pegawai akan meningkat. Hasil ini sejalan dengan penelitian yang dilakukan oleh Bakan, et.al (2014), Ezeanyim \& Ufoaroh (2019), Macutay (2020), yang mengemukakan bahwa kepuasan kerja mempengaruhi kinerja pegawai secara signifikan dalam suatu perusahaan.

\section{KESIMPULAN}

Berdasarkan hasil penelitian dapat disimpulkan bahwa rata-rata di Perum Bulog Sub Divre Bandung untuk kepemimpinan visioner dikategorikan baik, motivasi dikategorikan cukup, kompetensi masuk dalam kategori cukup tinggi, dan kepuasan kerja masuk dalam kategori cukup baik serta kinerja masuk dalam kategori cukup tinggi. Terdapat pengaruh yang signifikan secara parsial baik secara langsung maupun 
tidak langsung dari variabel kepemimpinan visioner terhadap kepuasan kerja. Terdapat pengaruh yang signifikan secara parsial baik secara langsung maupun tidak langsung dari variabel motivasi kerja terhadap kepuasan kerja. Terdapat pengaruh yang signifikan secara parsial baik langsung maupun tidak langsung dari variabel kompetensi terhadap kepuasan kerja. Terdapat pengaruh signifikan secara simultan baik langsung maupun tidak langsung dari variabel kepemimpinan visioner, motivasi kerja dan kompetensi terhadap kepuasan kerja. Terdapat pengaruh signifikan secara parsial baik langsung maupun tidak langsung kepuasan kerja terhadap kinerja pegawai sebesar.

\section{DAFTAR PUSTAKA}

Adam, F. and Kamase, J., 2019. The effect competence and motivation to satisfaction and performance. International Journal of Scientific \& Technology Research, 8(03), pp.132-140.

Anshar, M., 2017. The impact of visionary leadership, learning organization and innovative behavior to performance of customs and excise functional. Ijhcm (International Journal of Human Capital Management), 1(02), pp.52-60.

Arif, S., Zainudin, H.K. and Hamid, A., 2019. Influence of Leadership, Organizational Culture, Work Motivation, and Job Satisfaction of Performance Principles of Senior High School in Medan City. Budapest International Research and Critics Institute-Journal (BIRCI-Journal), pp.239-254.

Avolio, B.J., Waldman, D.A. and Einstein, W.O., 1988. Transformational leadership in a management game simulation: Impacting the bottom line. Group \& Organization Studies, 13(1), pp.59-80.

Bakan, I., Buyukbese, T., Ersahan, B. and Sezer, B., 2014. Effects of job satisfaction on job performance and occupational commitment. International Journal of Management \& Information Technology, 9(1), pp.1472-1480.

Bass, B.M, 1990. Bass and Stogdill's Hand Book of Leadership. New York; Free Press.

Coad, A.F. and Berry, A.J., 1998. Transformational leadership and learning orientation. Leadership \& Organization Development Journal.

Dessler. 2011. Human Resource management. Twelfth Edition, New Jersey, Pearson Prentice Hall. New York.

Ezeanyim, E.E. and Ufoaroh, E.T., 2019. The Impact of Job Satisfaction on Employee Performance in Selected Public Enterprise in Awka, Anambra State. Global Journal of Management And Business Research.

Finch, C. dan Crunkilton, J. R. 1979. Curriculum
Development in Vocational and Technical Education: Planning, Content and Implementation. Boston: Allyn and Bacon, Inc.

Gibson. 2012. Organizations Edition Business, Publication, Ins.

Guo, W., Li, T. and Wu, N., 2015. Empirical study on the effects of leader's verbal communication style on employee's job satisfaction. Journal of Human Resource and Sustainability Studies, 3(04), p.211.

Macutay, M.V., 2020. Quantitative Analysis Of Job Satisfaction And Job Performance Of Teaching Personnel Of Isabela State University. Journal of Critical Reviews, 7(11), pp.235-240.

Mangkunegara. 2016. Perencanaan dan Pengembangan Sumber Daya Manusia, Cetakan ketujuh, PT. Refika Aditama, Bandung.

Mukhtar, A. 2018. The Effect Of Competence And Organization Culture To Work Satisfaction And Employee Performance Of Sharia Banks In Makassar City', International Journal of Scientific \& Technology Research, 7(10).

Nanus, B., 1992. Visionary Leadership: Creating a Compelling Sense of Direction for Your Organization. Jossey-Bass Inc., 350 Sansome Street, San Francisco, CA 94104-1310.

Nindyati. 2013. Visionary Leadership Measurement in Indonesia, (The Implementation Visionary Leader from Burt Nanus Concept). International Conference on Business and Management Research (ICBMR), Seoul, November 7-8.

Posdakoff, P.M., MacKenzie, S.B. and Bommer, W. H., 1996. Transformational leader behavior and substitutes for leadership as determinants of employee satisfaction, commitment, trust and organisational citizenship behaviors. Journal of Management, 22(2), pp.259-289.

Renyut, B.C., Modding, H.B. and Bima, J., 2017. The effect of organizational commitment, competence on Job satisfaction and employees performance in Maluku Governor's Office.

Sastrohadiwinarto, B.S., 2005. Manajemen tenaga kerja Indonesia: Pendekatan administratif dan operasional.

Sunya, J., Basalamah, S., Gani, A. and Zakaria, J., 2017. The Influence Of Leadership, Competency, Motivation And Organizational Culture On Employees'Job Satifisfaction And Performance In Ternate City Government. International journal of Business Management, 2017, Vol, 2 (1): 1-11.

Xenikou, A. and Simosi, M., 2006. Organizational culture and transformational leadership as predictors of business unit performance. Journal of managerial psychology. 
Tabel 1. Kinerja Pelayanan Publik Perum Bulog Tahun 2014-2018 (Dalam Ton)

\begin{tabular}{cccc}
\hline No & Tahun & Pengadaan & Penyaluran \\
\hline 1. & 2014 & $2,624,799$ & $3,103,959$ \\
2. & 2015 & $2,611,583$ & $3,554,883$ \\
3. & 2016 & $3,510,101$ & $3,212,802$ \\
4. & 2017 & $2,051,341$ & $2,716,909$ \\
5. & 2018 & $3,275,884$ & $1,860,269$ \\
\hline
\end{tabular}

Sumber : Perum Bulog 2018

Tabel 2. Output Struktural 1

Correlations

\begin{tabular}{lrrrrr}
\hline \multicolumn{6}{c}{ Correlations } \\
\hline \multirow{4}{*}{ Pearson Correlation } & \multicolumn{1}{c}{$\mathrm{Y}$} & \multicolumn{1}{c}{$\mathrm{X}_{1}$} & \multicolumn{1}{c}{$\mathrm{X}_{2}$} & \multicolumn{1}{c}{$\mathrm{X}_{3}$} \\
& $\mathrm{Y}$ & 1.000 & .633 & .709 & .681 \\
& $\mathrm{X}_{1}$ & .633 & 1.000 & .584 & .444 \\
& $\mathrm{X}_{2}$ & .709 & .584 & 1.000 & .772 \\
Sig. (1-tailed) & $\mathrm{X}_{3}$ & .681 & .444 & .772 & 1.000 \\
& $\mathrm{Y}$ &. & .000 & .000 & .000 \\
& $\mathrm{X}_{1}$ & .000 &. & .000 & .000 \\
$\mathrm{~N}$ & $\mathrm{X}_{2}$ & .000 & .000 &. & .000 \\
& $\mathrm{X}_{3}$ & .000 & .000 & .000 &. \\
& $\mathrm{Y}$ & 105 & 105 & 105 & 105 \\
& $\mathrm{X}_{1}$ & 105 & 105 & 105 & 105 \\
& $\mathrm{X}_{2}$ & 105 & 105 & 105 & 105 \\
& $\mathrm{X}_{3}$ & 105 & 105 & 105 & 105 \\
\hline
\end{tabular}

Model Summary

\begin{tabular}{ccccccccccc}
\hline & & & \multicolumn{3}{c}{ Change Statistics } \\
Model & $\mathrm{R}$ & R Square & $\begin{array}{c}\text { Adjusted } \\
\text { R Square }\end{array}$ & $\begin{array}{c}\text { of the } \\
\text { Estimate }\end{array}$ & $\begin{array}{c}\text { R Square } \\
\text { Change }\end{array}$ & F Change & df1 & df2 & Change \\
\hline 1 & $.788^{\text {a }}$ & .621 & .610 & 5.15265 & .621 & 55.191 & 3 & 101 & .000 \\
\hline
\end{tabular}

a. Predictors: (Constant), $\mathrm{X}_{3}, \mathrm{X}_{1}, \mathrm{X}_{2}$

ANOVA $^{\mathrm{a}}$

\begin{tabular}{llccccc}
\hline Model & & Sum of Squares & df & Mean Square & F & Sig. \\
\hline 1 & Regression & 4395.906 & 3 & 1465.302 & 55.191 & $.000^{\mathrm{b}}$ \\
& Residual & 2681.531 & 101 & 26.550 & & \\
& Total & 7077.437 & 104 & & & \\
\hline
\end{tabular}

a. Dependent Variable: Y

b. Predictors: (Constant), $\mathrm{X}_{3}, \mathrm{X}_{1}, \mathrm{X}_{2}$

Coefficients $^{\mathrm{a}}$

\begin{tabular}{|c|c|c|c|c|c|c|c|c|c|}
\hline \multirow[b]{2}{*}{ Model } & & \multicolumn{2}{|c|}{$\begin{array}{c}\text { Unstandardized } \\
\text { Coefficients }\end{array}$} & \multirow{2}{*}{$\begin{array}{c}\begin{array}{c}\text { Standardized } \\
\text { Coefficients }\end{array} \\
\text { Beta }\end{array}$} & \multirow[b]{2}{*}{$\mathrm{t}$} & \multirow[b]{2}{*}{ Sig. } & \multicolumn{3}{|c|}{ Correlations } \\
\hline & & $\mathrm{B}$ & Std. Error & & & & Zero-order & Partial & Part \\
\hline \multirow[t]{4}{*}{1} & (Constant) & -.061 & 3.913 & & -.016 & .988 & & & \\
\hline & $\mathrm{X}_{1}$ & .364 & .082 & .336 & 4.458 & .000 & .633 & .405 & .273 \\
\hline & $\mathrm{X}_{2}$ & .263 & .112 & .251 & 2.360 & .020 & .709 & .229 & .145 \\
\hline & $\mathrm{X}_{3}$ & .363 & .103 & .338 & 3.507 & .001 & .681 & .329 & .215 \\
\hline
\end{tabular}

a. Dependent Variable: $Y$ 
Tabel 4. Output Struktural 2

Descriptive Statistics

\begin{tabular}{|c|c|c|c|c|}
\hline & Mean & \multicolumn{2}{|c|}{ Std. Deviation } & $\mathrm{N}$ \\
\hline $\mathrm{Z}$ & 49.9811 & \multicolumn{2}{|c|}{8.88054} & 105 \\
\hline Y & 49.1060 & \multicolumn{2}{|c|}{8.24938} & 105 \\
\hline \multicolumn{5}{|c|}{ Correlations } \\
\hline & & & $\mathrm{Z}$ & $\mathrm{Y}_{1}$ \\
\hline \multirow{2}{*}{\multicolumn{2}{|c|}{ Pearson Correlation }} & Z & 1.000 & .877 \\
\hline & & $\mathrm{Y}$ & .877 & 1.000 \\
\hline \multirow{2}{*}{\multicolumn{2}{|c|}{ Sig. (1-tailed) }} & Z & . & .000 \\
\hline & & Y & .000 & . \\
\hline \multirow[t]{2}{*}{$\mathrm{N}$} & & Z & 105 & 105 \\
\hline & & Y & 105 & 105 \\
\hline
\end{tabular}

Model Summary

\begin{tabular}{|c|c|c|c|c|c|c|c|c|c|}
\hline \multirow[b]{2}{*}{ Model } & \multirow[b]{2}{*}{$\mathrm{R}$} & \multirow[b]{2}{*}{ R Square } & \multirow[b]{2}{*}{$\begin{array}{l}\text { Adjusted } \\
\text { R Square }\end{array}$} & \multirow{2}{*}{$\begin{array}{l}\text { Std. Error } \\
\text { of the } \\
\text { Estimate }\end{array}$} & \multicolumn{5}{|c|}{ Change Statistics } \\
\hline & & & & & $\begin{array}{l}\text { R Square } \\
\text { Change }\end{array}$ & F Change & df1 & $\mathrm{df} 2$ & $\begin{array}{l}\text { Sig. F } \\
\text { Change }\end{array}$ \\
\hline 1 & $.877^{\mathrm{a}}$ & .769 & .730 & 4.61753 & .769 & 281.674 & 1 & 103 & .000 \\
\hline
\end{tabular}

a. Predictors: (Constant), Y

\section{ANOVA $^{\mathrm{a}}$}

\begin{tabular}{llccccc}
\hline Model & & Sum of Squares & df & Mean Square & F & Sig. \\
\hline 1 & Regression & 6005.727 & 1 & 6005.727 & 281.674 & $.000^{\text {b }}$ \\
& Residual & 2196.122 & 103 & 21.322 & & \\
& Total & 8201.849 & 104 & & & \\
\hline
\end{tabular}

a. Dependent Variable: $Z$

b. Predictors: (Constant), Y

Coefficients $^{\mathrm{a}}$

\begin{tabular}{|c|c|c|c|c|c|c|c|c|c|}
\hline \multirow[b]{2}{*}{ Model } & & \multicolumn{2}{|c|}{$\begin{array}{l}\text { Unstandardized } \\
\text { Coefficients }\end{array}$} & \multirow{2}{*}{$\begin{array}{c}\text { Standardized } \\
\text { Coefficients }\end{array}$} & \multirow[b]{2}{*}{$\mathrm{t}$} & \multirow[b]{2}{*}{ Sig. } & \multicolumn{3}{|c|}{ Correlations } \\
\hline & & $\mathrm{B}$ & Std. Error & & & & Zero-order & Partial & Part \\
\hline \multirow[t]{2}{*}{1} & (Constant) & 4.746 & 2.733 & & 1.737 & .085 & & & \\
\hline & $\mathrm{Y}$ & .921 & .055 & .877 & 16.783 & .000 & .877 & .877 & .877 \\
\hline
\end{tabular}

a. Dependent Variable: $\mathrm{Z}$ 